\title{
Определение антоцианов лепестков астр китайских, Callistephus chinensis, методом обращенно-фазовой ВЭЖХ
}

\author{
Кульченко Я.Ю. ${ }^{1}$, Дейнека В.И. ${ }^{1}$, Чулков А.Н. ${ }^{2}$, Сидоров А.Н. ${ }^{1}$, \\ Дейнека Л.А. ${ }^{1}$, Селеменев В.Ф. ${ }^{3}$ \\ ${ }^{I}$ ФГАОУ ВО «Белгородский государственный наииональный исследовательский университет», \\ Белгород \\ ${ }^{2}$ ФГБУ Белгородский филиал «Центр оиенки качества зерна и продуктов его переработки», Белгород \\ ${ }^{3}$ ФГБОУ ВО «Воронежский государственный университет», Воронеж
}

Поступила в редакцию 23.05.2018 г.

DOI: https://doi.org/10.17308/sorpchrom.2018.18/567

В работе методом обращенно-фазовой ВЭЖХ определен видовой состав антоциановых комплексов лепестков цветков нескольких сортов астры китайской Callistephus chinensis. Найдено, что в лепестках всех исследованных образцов антоцианы построены на трех агликонах: дельфинидине, цианидине и пеларгонидине. Установлено, что для большинства сортов характерен биосинтез либо 3глюкозидов, либо 3,5-диглюкозидов этих антоцианидинов, включая ацилированные малоновой кислотой, хотя для одного из образцов получена сложная смесь, включающая оба типа гликозилирования. Показано, что среди малонированных антоцианов один является доминирующим; ему обычно сопутствуют (в небольших количествах) изомеры по положению ацилирования глюкозидных радикалов, а дималонированные производные не были обнаружены ни в одном из исследованных экстрактов.

Ключевые слова: ВЭЖХ, антоцианы, Callistephus chinensis, неметилированные агликоны, 3глюкозиды, 3,5-диглюкозиды, малонированные антоцианы.

\section{Determination of Callistephus chinensis flower petals anthocyanins by reverse-phase HPLC}

\author{
Kulchenko Ya.Yu. ${ }^{1}$, Deineka V.I. ${ }^{1}$, ChulkovA.N. ${ }^{2}$, Sidorov A.N. ${ }^{1}$, \\ Deineka L.A. ${ }^{1}$, Selemenev V.F. ${ }^{3}$ \\ ${ }^{l}$ Belgorod National Research University, Belgorod \\ ${ }^{2}$ Belgorod branch of «Centre of evaluation of quality of grain and products of its processing», Belgorod \\ ${ }^{3}$ Voronezh State University, Voronezh
}

The specific composition of anthocyanin types of flower petals of Callistephus chinensis several varieties is determined by the inverse-phase HPLC method with mass-spectrometric and diode array detection. It was found that in the petals of all the samples under investigation anthocyanins were synthesized upon non-methylated aglycones, delphinidin, cyanidin and pelargonidin, proving the absence in flower cells methyl transferase. It was also established that two types of anthocyanin biosynthesis may result in accumulation of either 3-glucosides (3G) or 3,5-diglucosides (3,3diG) of some of above mentioned aglycones depending upon flower cultivars, with high degree of acylation by malonic acid. This results are in full agreement wiyh known literature data. The main acylation products (in position 6 of 3-glucosidic substituents) was accomplished by small quantities of isomers being malonated in position 2 of 4 of sugar substituent, but not at 
3 position. All main possible types of anthocyanins may be separated by proposed method, but one cultivar with more complex anthocyanin composition was also found. In this case substantial quantities of $3 \mathrm{G}$ simultaneously with 3,5diG type of anthocyanins were present. Hence new type of inheritance of characters was received by the breeders. Results of retention analysis indicated that retention of anthocyanins after acylation by malonic acid (in logarithms units of retention factor) depends mainly upon the type of glycosylation and position of acylation rather than upon aglycone type and upon mobile phase composition. Meanwhile the retention of anthocyanins is a complex function of aglycon and the sugar moieties structures.

Keywords: reversed-phase HPLC, anthocyanins, Callistephus chinensis, non-methylated aglycones, 3-glucosides, 3,5-diglucosides, malonated anthocyanins.

\section{Введение}

Нетрадиционные (не относящиеся к съедобным фруктам и овощам), возобновляющиеся источники антоцианов представляют важный технологический интерес для получения природных красителей с антиоксидантной функцией. К числу таких источников можно отнести популярные у садоводов-любителей осенние цветы повсеместно выращиваемого однолетнего растения, называемого часто астрами, на самом деле относящимися к роду Callistephus; их точное ботаническое название $C$. chinensis (L.) Nees - каллистефус китайский. Окраска цветков этих растений от красной до синей обусловлена биосинтезом антоцианов.

В обстоятельной работе [1], посвященной в основном генетическим аспектам растений, для определения антоцианов использовали метод ТСХ на пластинах с целлюлозой. При этом было установлено, что многообразие антоцианов цветков астр китайских обусловлено, во-первых, биосинтезом 3-глюкозидов или 3,5диглюкозидов пеларгонидина, цианидина и дельфинидина, табл.1. Во-вторых, они могут быть ацилированы кислотой, отличающейся от гидроксикоричных, давая по два продукта для каждого из гликозидов. Об ацилировании было установлено, что оно легко снимается в кислых средах, поэтому авторы применили экстракцию смесью, обозначенную авторами как $0.1 \%$ метанол - $\mathrm{HCl}$ при $4^{\circ} \mathrm{C}$. Кроме того, найдено, что при контролируемом гидролизе одного из ацилированных продуктов получается второй ацилированный продукт, неацилированный гликозид и агликон, тогда как при аналогичном превращении другого - только два последних вещества.

Таблица 1. Антоцианы шести генотипов каллистефуса китайского [1]

\begin{tabular}{|c|c|c|c|c|c|c|}
\hline 1 & $\mathrm{rrmm}$ & r'r'mm & RRmm & rrMM & r'r'MM & RRMM \\
\hline 1 & 2 & 3 & 4 & 5 & 6 & 7 \\
\hline Pg3G & ++ & ++ & - & \multirow{9}{*}{\multicolumn{3}{|c|}{$\begin{array}{c}\text { 3-моноглюкозиды встречают- } \\
\text { ся только в следовых количе- } \\
\text { ствах }\end{array}$}} \\
\hline Pg3G ацилированный I & ++++ & +++ & +- & & & \\
\hline Pg3G ацилированный II & ++ & + & - & & & \\
\hline Cy3G & + & ++ & + & & & \\
\hline Су3G ацилированный I & ++ & +++ & ++ & & & \\
\hline Су3G ацилированный II & +- & ++ & +- & & & \\
\hline $\mathrm{Dp} 3 \mathrm{G}$ & - & + & ++ & & & \\
\hline Dp3G ацилированный I & - & ++ & ++++ & & & \\
\hline Dp3G ацилированный II & - & + & ++ & & & \\
\hline $\operatorname{Pg} 3,5 \mathrm{diG}$ & \multirow{9}{*}{\multicolumn{3}{|c|}{$\begin{array}{c}\text { 3,5-диглюклзиды } \\
\text { не обнаружены }\end{array}$}} & ++ & + & - \\
\hline Pg3,5diG ацилированный I & & & & ++++ & ++ & +- \\
\hline Pg3,5diG ацилированный II & & & & ++ & + & - \\
\hline Cy3,5diG & & & & + & ++ & + \\
\hline Су3,5diG ацилированный I & & & & ++ & +++ & ++ \\
\hline Су3,5diG ацилированный II & & & & $?$ & $?$ & $?$ \\
\hline Dp3,5diG & & & & - & + & ++ \\
\hline Dp3,5diG ацилированный I & & & & - & ++ & ++ \\
\hline Dp3,5diG ацилированный II & & & & - & $?$ & $?$ \\
\hline
\end{tabular}

Кульченко и др. / Сорбционные и хроматографические процессы. 2018. Т. 18. № 4 
В другом исследовании, посвященном распространенности малонированных антоцианов в цветках растений семейства сложноцветные [2], ацилированное производное пеларгонидина описывают как пеларгонидин-3-(6"-малонилглюкозид), причем такое отнесение было подтверждено масс-спектрометрическим исследованием, обнаружением малоновой кислоты в продуктах гидролиза антоцианов и хроматографическим определением 6-малонилглюкозы в продуктах окисления антоцианов пероксидом водорода. Отсутствие в продуктах гидролиза дималонил-производных 3,5-диглюкозидов (определенных методом масс-спектрометрии) дималонилглюкозы свидетельствовало о том, что в данном случае ацилированы оба радикала глюкозы в положениях 3 и 5. О двух ацилированных продуктах 3-глюкозидов, о которых сообщалось в работе [1], информация отсутствовала вообще. И хотя авторы [2] применили технику высокоэффективной хроматографии, по странному обычаю журналов данного профиля хроматограммы не приводятся, поэтому анализ полноты идентификации невозможен, однако ранее полученные результаты не были подтверждены полностью. В работе [3] сообщалось о выделении фермента, осуществляющего малонирование положения 6 глюкозидного фрагмента в 3-глюкозидах пеларгонидина, цианидина и дельфинидина, а также (но уже с меньшей скоростью) радикалов в 3,5диглюкозидах тех же агликонов.

Многие работы по исследованию антоцианов (и активности соответствующих ферментов [1-3]) проводились, как правило, методом бумажной хроматографии, поскольку к тому времени техника ВЭЖХ еще не была доступной. Поэтому настоящая работа является первым обстоятельным анализом антоцианов цветков каллистефуса китайского, выполненного с использованием современных технологий ВЭЖХ с масс-спектрометрическим и диодно-матричным детектированием. Исследование современного растительного материала имеет большое значение в свете значительного прогресса в селекции растений, включающей методы генной инженерии, что привело к получению высокодекоративных сортов.

\section{Эксперимент}

Разделение осуществляли на оборудовании Agilent 1200 Infinity с диодноматричным и масс-спектрометрическим детекторами. В работе использовали хроматографические колонки: $250 \times 4.6$ мм Symmetry C18 (5 мкм) - для серийных исследований и $150 \times 2.1$ мм Kromasil 100-5C18 - при масс-спектрометрическом детектировании. Мертвое время определяли по урацилу. Хроматограммы регистрировали и обрабатывали программой ChemStation. Для элюирования использовали элюенты: 10 об. \% НСООН и 4-10 об. \% $\mathrm{CH}_{3} \mathrm{CN}$ в воде. При построении карты разделения использовали изократические режимы для четырех элюентов, в которых постоянным оставалось содержание муравьиной кислоты (10 об. \%), а содержание ацетонитрила и воды составляло 4 и 86, 6 и 84, 8 и 82, 10 и 80 об. \%, соответственно. Во всех случаях скорость подачи подвижной фазы была постоянной $-0.8 \mathrm{~cm}^{3} / \mathrm{Mин,} \mathrm{а} \mathrm{температу-}$ ра термостата колонки $40^{\circ} \mathrm{C}$.

Лепестки цветков сушили в лабораторном суховоздушном термостате ТС 1/20 СПУ при $30^{\circ} \mathrm{C}$. Экстракты готовили настаиванием свежих или высушенных лепестков цветков в $0.1 \mathrm{M}$ водном растворе $\mathrm{HCl}$. Перед хроматографированием экстракты, отделенные от остатка фильтрованием через бумажный фильтр, очищали методом твердофазной экстракции на концентрирующих патронах Диапак С18 (БиохимМак СТ, Москва).

Для удобства контроля разделения компонентов экстрактов принята сложная система обозначения, по которой первые цифры 1, 2 и 3 соответствуют дельфиниди-

Кульченко и др. / Сорбционные и хроматографические процессы. 2018. Т. 18. № 4 
ну, цианидину и пеларгонидину. Вторая цифра обозначает: 1 - 3-глюкозиды, 2 - 3,5диглюкозиды. Третья цифра указывает на отсутствие (0) или наличие (1) малонирования.

\section{Обсуждение результатов}

Определение видового состава антоцианов. По результатам выполненных в данной работе исследований, следует, что, во-первых, антоциановый комплекс может включать только антоцианы, построенные на основе дельфинидина, цианидина и пеларгонидина. Это является следствием отсутствия биосинтеза метилтрансферазы, - фермента, необходимого для биосинтеза антоцианов на основе метилированных агликонов (петунидина, мальвидина и пеонидина). Во-вторых, возможен биосинтез 3-глюкозидов и/или 3,5-диглюкозидов указанных агликонов. В-третьих, в экстрактах кроме соответствующих глюкозидов обнаруживаются продукты их мономалонирования с одним доминирующим типом ацилирования. Состав указанных антоцианов подтвержден параметрами УФ- и масс-спектров, табл.1. Кроме того гликозилирование антоцианидинов по положению 3 или по положениям 3 и 5 именно глюкозой, а не иной гексозой, что не может быть определено анализом спектров поглощения и масс-спектров, было подтверждено хроматографическим методом. Для этого сопоставляли удерживание продуктов спонтанного деацилирования малонированных производных при хранении при комнатной температуре в течение 2-х месяцев с образцами 3-глюкозидов (из экстракта плодов Vitis vinufera) и 3,5-диглюкозидов (из экстракта плодов Vitis coignetiae) антоцианидинов из коллекции лаборатории. Отметим, что удерживание 3-глюкозидов и 3-галактозидов одинаковых агликонов различается весьма значительно, что делает такое определение однозначным.

Таким образом, необходим метод разделения, как минимум, 12-ти основных возможных компонентов антоциановых комплексов. Карта разделения для выбранной в работе хроматографической системы представлена на рис. 1. Эта карта значительно упрощается с учетом предполагаемой по литературным данным специфике биосинтеза - возможного обнаружения либо производных 3-глюкозидов (рис.1, 3G), либо производных 3,5-диглюкозидов (рис.1, 3,5diG) [1].

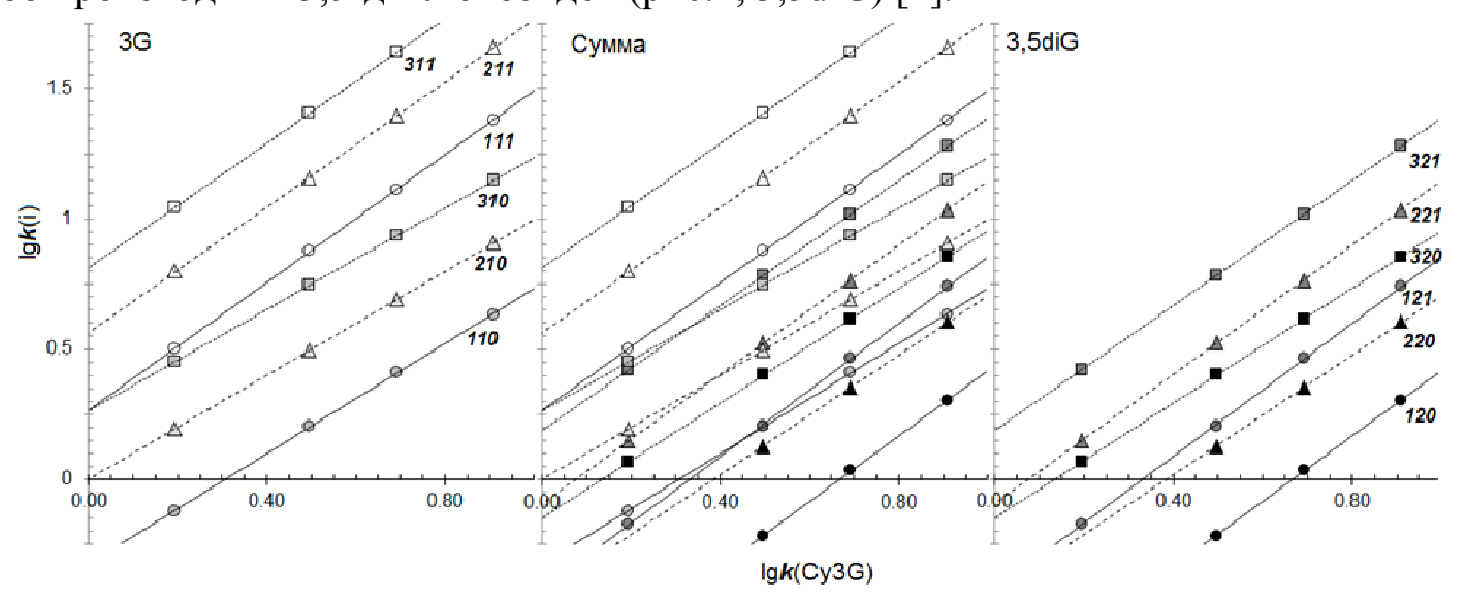

Рис. 1. Карта разделения антоцианов цветков C. chinensis

Хроматографическая система: стационарная фаза Symmetry C18, подвижные фазы системы « $\mathrm{CH}_{3} \mathrm{CN}$ - 10 об. \% $\mathrm{HCOOH}$ - вода». Цифровое обозначение антоцианов - см. текст.

На рис.2 приведена хроматограмма антоцианов цветка розового цвета сорта Мальвина. В этом случае антоциановый комплекс образован в основном 3- 
глюкозидами цианидина и пеларгонидина и продуктами их малонирования. Хроматографические методы на настоящей стадии развития количественных методов, связывающих удерживание веществ с их строением (QSRR), не позволяют определить строение малонированных производных напрямую. Но направление ацилирования глюкозидного радикала малоновой кислотой может быть установлено сопоставлением удерживания производных цианидина этого экстракта с производными цианидин3-глюкозида, ацилированного малоновой кислотой из экстракта оберток пурпурной кукурузы [4]. Такой подход позволяет определить строение соединения, которому соответствует пик (211) на хроматограмме на рис.2, как цианидин-3-(6"малонилглюкозид). Но при этом ни один из пиков (212) и (213) (такую нумерацию необходимо ввести вследствие иного направления малонирования) не соответствует цианидин-3-(3"'-малонилглюкозиду), и поэтому относится либо к 2"малонилглюкозиду, либо к 4"-малонилглюкозиду. Аналогичные вещества присутствуют, причем также в минорных количествах, в экстракте оберток пурпурной кукурузы вместе с цианидин-3-(6"-малонилглюкозидом) и цианидин-3-(3"малонилглюкозидом). Возможно, что присутствие веществ (212) и (213) в минорных количествах является следствием спонтанной переэтерификации малонированных антоцианов вследствие высокой лабильности продуктов ацилирования этой кислотой. Используя ранее предложенный вариант сравнительного анализа удерживания однотипных производных различных агликонов [5], можно определить идентичные производные других агликонов, которые могут быть обнаружены на хроматограммах (см. вставку на рис.1).

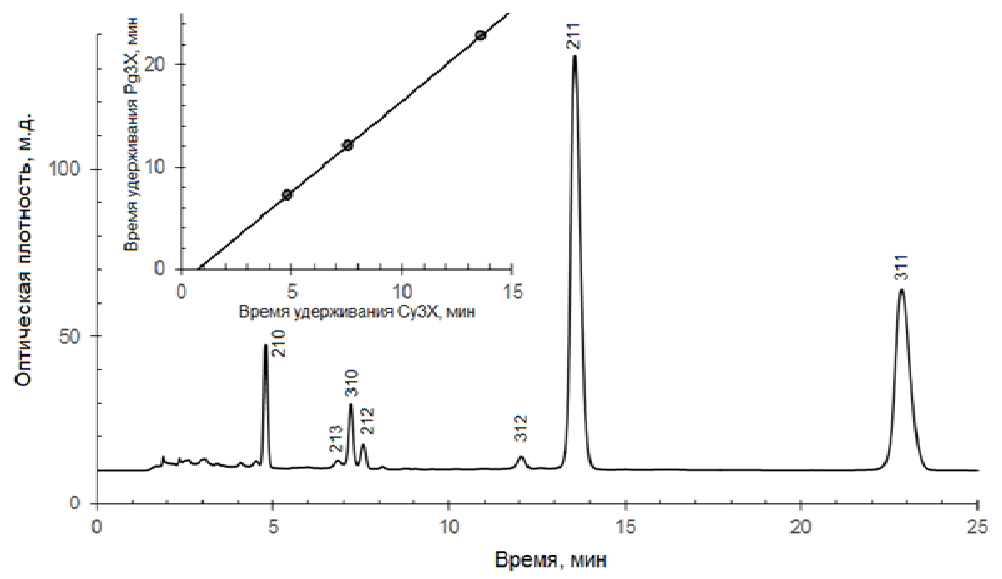

Рис. 2. Разделение антоцианов цветков астры китайской сорта Мальвина Хроматографическая колонка: 4.5×150 мм Symmetry C18, 3.5 мкм; подвижная фаза: 6 об. \% $\mathrm{CH}_{3} \mathrm{CN}$ и 10 об. \% НСООН в воде, $0.8 \mathrm{~cm}^{3} /$ мин. Запись при 515 нм.

Фиолетовая окраска цветков обычно связана с биосинтезом производных дельфинидинового ряда. И действительно, в лепестках цветков сортов астр китайских фиолетового цвета антоциановый состав меняется на такой же набор производных, но с частичной сменой базовых агликонов - к производным цианидина добавляются производные не пеларгонидина, а дельфинидина, либо производные дельфинидина становятся доминирующими антоцианами, табл.3. Еще один тип набора антоцианов, обнаруженных в исследованных в настоящей работе сортах (табл.2), отличается биосинтезом 3,5-диглюкозидов вместо 3-глюкозидов, что соответствует литературным данным. Причем, в некоторых случаях на хроматограммах находили небольшие пики, относящиеся, предположительно, к изомерным основным мономалонированным 3.5-диглюкозидам антоцианов. 
Таблица 2. Экспериментальные характеристики видов антоцианов каллистефуса китайского

\begin{tabular}{|c|c|c|c|c|c|}
\hline \multirow{2}{*}{ Вид антоциана } & \multicolumn{2}{|c|}{ Обозначение } & \multirow{2}{*}{$t_{\mathrm{R}}$, мин* } & \multirow{2}{*}{$\lambda_{\max }, \mathrm{HM}$} & \multirow{2}{*}{$\mathrm{M} / \mathrm{z}$} \\
\hline & буквенное & числовое & & & \\
\hline $\begin{array}{c}\text { Дельфинидин } \\
-3,5 \text {-диглюкозид }\end{array}$ & Dp3,5diG & 120 & 2.34 & 522 & 627.1 \\
\hline $\begin{array}{l}\text { Дельфинидин } \\
\text {-3-глюкозид }\end{array}$ & Dp3G & 110 & 4.19 & 523 & 465.1 \\
\hline $\begin{array}{c}\text { Дельфинидин } \\
\text {-3-(6"-малонилглюкозид) } \\
\text {-5-глюкозид }\end{array}$ & $\begin{array}{c}\text { Mal- } \\
\text { Dp3,5diG }\end{array}$ & 121 & 2.90 & 523 & 713.1 \\
\hline $\begin{array}{c}\text { Дельфинидин } \\
-3-(6 "-\text {-малонилглюкозид) }\end{array}$ & Mal-Dp3G & 111 & 7.86 & 524 & 551.1 \\
\hline Цианидин-3,5-диглюкозид & Су3,5diG & 220 & 2.85 & 514 & 611.1 \\
\hline Цианидин-3-глюкозид & Cy3G & 210 & 4.76 & 515 & 449.1 \\
\hline $\begin{array}{c}\text { Цианидин-3- } \\
\text { (6"-малонилглюкозид)-5-глюкозид }\end{array}$ & $\begin{array}{c}\text { Mal- } \\
\text { Cy3,5diG }\end{array}$ & 221 & 4.40 & 515 & 697.1 \\
\hline $\begin{array}{c}\text { Цианидин-3- } \\
\text { (6"-малонилглюкозид) }\end{array}$ & Mal-Cy3G & 211 & 13.56 & 516 & 535.1 \\
\hline $\begin{array}{c}\text { Пеларгонидин-3,5 } \\
\text {-диглюкозид }\end{array}$ & $\mathrm{Pg} 3,5 \mathrm{diG}$ & 320 & 4.05 & 500 & 595.1 \\
\hline $\begin{array}{c}\text { Пеларгонидин } \\
\text {-3-глюкозид }\end{array}$ & $\mathrm{Pg} 3 \mathrm{G}$ & 310 & 7.51 & 500 & 433.1 \\
\hline $\begin{array}{c}\text { Пеларгонидин-3 } \\
\text {-(6"-малонилглюкозид)-5-глюкозид }\end{array}$ & $\begin{array}{c}\text { Mal- } \\
\text { Pg3,5diG }\end{array}$ & 321 & 6.85 & 501 & 681.1 \\
\hline $\begin{array}{c}\text { Пеларгонидин-3- } \\
\text { (6"-малонилглюкозид) } \\
\end{array}$ & Mal-Pg3G & 311 & 23.76 & 501 & 519.1 \\
\hline
\end{tabular}

*- подвижная фаза 8 об.\% ацетонитрила и 10 об.\% муравьиной кислоты в воде

Таблица 3. Антоциановый состав лепестков цветков некоторых сортов астр китайских

\begin{tabular}{|c|c|c|c|c|c|c|c|c|c|c|c|c|}
\hline & $\begin{array}{l}0 \\
\stackrel{0}{n} \\
\tilde{n} \\
\hat{n}\end{array}$ & $\begin{array}{l}\tilde{n} \\
\hat{\tilde{\theta}}\end{array}$ & 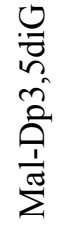 & 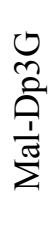 & 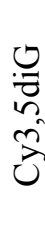 & త্ & 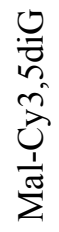 & 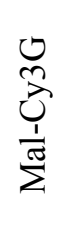 & 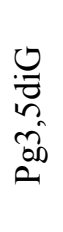 & 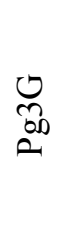 & 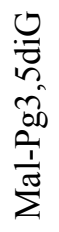 & $\begin{array}{l}0 \\
0 \\
\tilde{D}_{0}^{\infty} \\
\frac{1}{\pi}\end{array}$ \\
\hline 1 & 2 & 3 & 4 & 5 & 6 & 7 & 8 & 9 & 10 & 11 & 12 & 13 \\
\hline $\begin{array}{l}\text { Клеопатра } \\
\text { фиолетовая }\end{array}$ & $\stackrel{0}{2}$ & I & $\stackrel{0}{0}$ & ' & $\hat{0}$ & ' & $\stackrel{n}{f}$ & ' & I & & & \\
\hline $\begin{array}{c}\text { Коко } \\
\text { Шанель }\end{array}$ & $\stackrel{?}{+}$ & ' & $\stackrel{\circ}{I}$ & ' & $\tilde{o}$ & ' & $\vec{r}$ & ' & ' & & & \\
\hline $\begin{array}{l}\text { Синяя } \\
\text { башня }\end{array}$ & $\stackrel{\check{ \pm}}{\dot{I}}$ & ' & o. & ' & ' & ' & $\vec{m}$ & ' & ' & & & \\
\hline $\begin{array}{c}\text { Глория } \\
\text { синяя }\end{array}$ & $\overline{\mathfrak{I}}$ & ' & $\hat{i}$ & ' & $\tilde{0}$ & ' & $\vec{m}$ & ' & ' & & 9 & \\
\hline $\begin{array}{c}\text { Фиолетовая } \\
\text { Башня }\end{array}$ & $\ddot{n}$ & 1 & $\grave{\dot{\infty}}$ & ' & $\stackrel{\infty}{0}$ & I & $\overrightarrow{\text { ले }}$ & ' & 1 & & I & \\
\hline
\end{tabular}




\begin{tabular}{|c|c|c|c|c|c|c|c|c|c|c|c|c|}
\hline 1 & 2 & 3 & 4 & 5 & 6 & 7 & 8 & 9 & 10 & 11 & 12 & 13 \\
\hline Дарьюшка & ' & ' & $\underset{\infty}{+}$ & 1 & 1 & 1 & 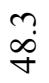 & 1 & ' & & $\stackrel{+}{\dot{q}}$ & \\
\hline Анита & 1 & 1 & $\stackrel{\sim}{m}$ & 1 & 1 & 1 & $\stackrel{a}{\Delta}$ & 1 & 1 & & $\hat{n}$ & \\
\hline Рубин & 1 & ' & ' & ' & 1 & ' & ' & 1 & $\begin{array}{l}m \\
\sim \\
\sim\end{array}$ & & $\begin{array}{l}\infty \\
\ddot{b}\end{array}$ & \\
\hline Вероника & 1 & ' & ナे & ' & ' & 1 & ' & ' & ' & & & \\
\hline Клеопатра красная & 1 & ' & 1 & ' & 1 & $\overrightarrow{0}$ & 1 & 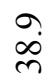 & ' & $\begin{array}{l}\infty \\
\stackrel{0}{0}\end{array}$ & & ষ \\
\hline Гиг.лучи & 1 & 1 & 1 & ' & 1 & $\stackrel{0}{-}$ & 1 & $\underset{\sim}{\infty}$ & 1 & nֶ. & & $\stackrel{N}{N}$ \\
\hline Эсмеральда. & 1 & ' & ' & ' & ' & $\stackrel{a}{\infty}$ & 1 & ఫे & ' & $\vec{\infty}$ & & $n$ \\
\hline Темно-красная & 1 & ' & 1 & ' & 1 & $\stackrel{\circ}{-}$ & 1 & $\stackrel{\infty}{\forall}$ & ' & $\begin{array}{l}0 \\
n\end{array}$ & & $\stackrel{0}{2}$ \\
\hline Станислав & 1 & ' & 1 & ' & 1 & $\stackrel{r}{r}$ & 1 & 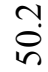 & ' & $\hat{\sigma}$ & & m \\
\hline $\begin{array}{c}\text { Аполлонная } \\
\text { красная }\end{array}$ & I & ' & ' & ' & ' & $\vec{\sigma}$ & 1 & $\begin{array}{l}0 \\
\text { in }\end{array}$ & ' & $m$ & & 尺 \\
\hline Скарлет & ' & ' & ' & 1 & ' & $\stackrel{m}{m}$ & ' & ָั & 1 & $\stackrel{9}{r}$ & & $\overline{6}$ \\
\hline $\begin{array}{c}\text { Н/сорт* } \\
\text { (фиолетовые) }\end{array}$ & $\grave{0}$ & $\stackrel{\circ}{+}$ & $\dot{0}$ & $\hat{\sigma}$ & $\begin{array}{l}0 \\
\dot{J}\end{array}$ & $\overparen{r}$ & $\stackrel{\leftrightarrow}{\stackrel{\rho}{~}}$ & $\ddot{n}$ & $\vec{a}$ & $\tilde{n}$ & $\stackrel{\simeq}{\beth}$ & $\underbrace{\infty}$ \\
\hline
\end{tabular}

* - неизвестный сорт

В цветках фиолетовой окраски неизвестного сорта, рис.3, были найдены не только 3,5-диглюкозиды дельфинидина, цианидина и пеларгонидина, включая моноацилированные малоновой кислотой, но обнаружен и высокий уровень накопления производных 3-глюкозидов. А это не полностью согласуется с результатами генетического анализа биосинтеза антоцианов в работе [1]. Следовательно, усилиями селекционеров в последнее время получены новые гибриды, требующие расширения возможных вариантов наследования признаков, хотя во многих случаях классификация [1] все-таки подтверждается.

Отметим, что распознавание антоцианов цветков астры китайской легко осуществляется даже по спектрам поглощения с дополнением по контролю удерживания. Так различие в электронных спектрах 3-глюкозидов всех трех агликонов велико настолько, что дифференциации не мешает сольватохромный эффект (смещение максимумов абсорбции не превышало 1 нм во всем диапазоне использованных составов подвижных фаз): зависимость параметров спектров от содержания ацетонитрила заметно меньше, чем от строения агликона. Дифференциация между 3глюкозидами и 3,5-диглюкозидами также осуществляется просто, - по характеристи- 
ческому изменению, - исчезновению локального максимума около 430 нм и по небольшому гипсохромному смещению максимума абсорбции (см. вставку на рис.3) в дополнение к заметно большему относительному уширению пиков по сравнению с пиками 3-глюкозидов. Наконец, малонирование мало сказывается на электронных спектрах: наблюдается лишь небольшой батохромный сдвиг максимумов абсорбции (менее 1 нм).

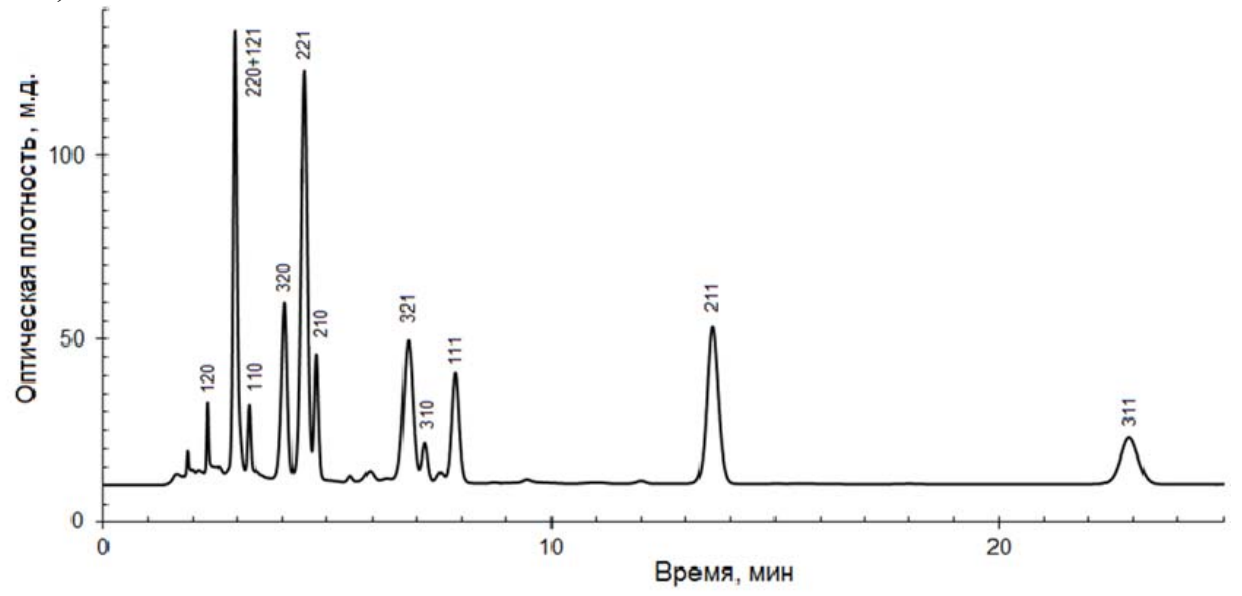

Рис. 3. Разделение антоцианов лепестков цветков C. chinensis фиолетового цвета. Условия записи см. подпись к рис.2.

Анализ зависимости удерживания антоцианов от строения. Постулированный ранее [6] поплавочный механизм удерживания предполагает проникновения флавилиевой части внутрь привитой фазы. При этом ориентация кольца В может иметь важное значение. Так, при переходе от производных пеларгонидина к производным цианидина из двух возможных конформаций флавилиевого фрагмента конформация II (рис.4) предпочтительна для внедрения в гидрофобную привитую фазу. В данном случае гидрофильность молекулы частично маскируется ориентацией гидроксильной группы в сторону гидрофильного углеводного радикала. Для дельфинидина такой возможности нет, поэтому при переходе для однотипных соединений агликонов цианидин $\rightarrow$ дельфинидин удерживание уменьшается больше, чем для пары пеларгонидин $\rightarrow$ цианидин. Понятно, что аналогичное изменение сохраняется и для 3,5диглюкозидов, рис.5, хотя инкременты для всех соответствующих возможных пар заметно различаются между собой и по-разному изменяются при изменении состава подвижной фазы.

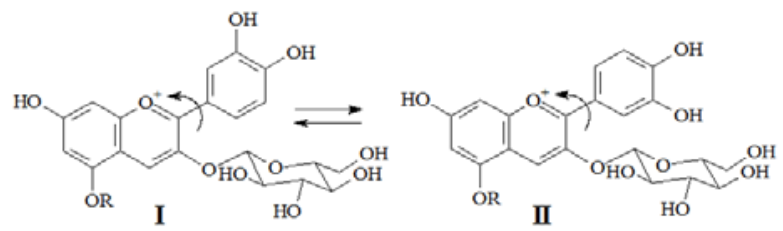

Рис. 4. Две конформации цианидин-3-глюкозида

Ацилирование малоновой кислотой в положение 6 глюкозидного радикала приводит к существенному росту удерживания - на 0.7-0.8 логарифмических единиц факторов удерживания для 3-глюкозидов всех трех агликонов с относительно небольшими различиями по строению агликона и по составу подвижной фазы. При этом рост удерживания вследствие ацилирования 3-глюкозидов больше, чем для 3,5диглюкозидов, рис.5. Наконец, заметных количеств дималонированных 3,5диглюкозидов и 3-глюкозидов всех трех агликонов в настоящей работе не было обнаружено. 


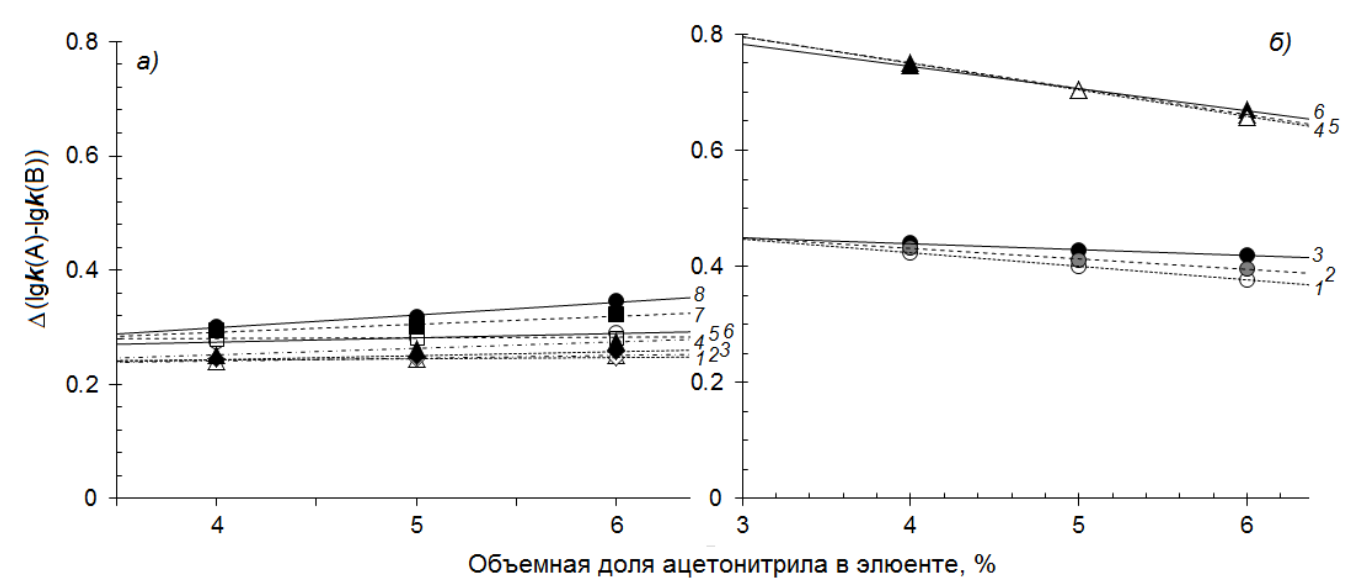

Рис. 5. Зависимость изменения логарифмов факторов удерживания антоцианов при а) удалении ОН-группы в кольцо В агликона; б) при ацилировании антоцаинов малоновой кислотой. Начальные антоцианы соответствующих парах: а): $1-211$, 2 - 210, 3 - 221, 4 - 220, 5 - 111, 6 - 110, 7 - 121, 8 - 120; б): 1 - 220, 2 - 120, 3 - 320, $4-210,5-310,6-110$.

\section{Заключение}

В работе впервые методом обращенно-фазовой ВЭЖХ проведен анализ антоцианов большой группы сортов астры китайской. При этот показано, что известная классификация сортов по наследованию признака - характера биосинтеза антоцианов в целом соблюдается для современных сортов, исследованных в работе, но обнаружены и отклонения от указанной классификации. Определены основные зависимости удерживания антоцианов от строения агликонов и от ацилирования малоновой кислотой.

\section{Список литературы}

1. Forkmann G. // Phytochem. 1977. Vol. 16. pp. 299-301.

2. Takeda K., Harborne J.B., Self R. // Phythochem. 1986. Vol. 25. pp. 1337-1342.

3. Teusch M., Forkmann G. // Phytochem. 1987. Vol. 26. pp. 2181-2183.

4. Дейнека В.И., Сидоров А.Н., Дейнека Л.А. // Журнал аналитической химии. 2016. T. 71. C. 1203-1208.

\section{References}

1. Forkmann G., Phytochem., 1977, Vol. 16, pp. 299-301. https://doi.org/10.1016/S00319422(00)86818-1

2. Takeda K., Harborne J.B., Self R., Phythochem., 1986, Vol. 25, pp. 1337-13421. https://doi.org/10.1016/S0031-9422(00)812856.
5. Дейнека В.И., Кульченко Я.Ю., Дейнека Л.А. и др. // Сорбиионные и хроматографические прочессы. 2016. Т. 16. № 4. С. 464471.

6. Дейнека В. И., Дейнека Л.А., Саенко И.И. и др. // Журнал физической химии. 2015. Т. 89. С. 1172-1177.
3. Teusch M., Forkmann G., Phytochem., 1987, Vol. 26, pp. 2181-2183. https://doi.org/ 10.1016/S0031-9422(00)84680-4.

4. Deineka V.I., Sidorov A.N., Deineka L.A., Journal of Analytical Chemistry, 2016, Vol. 71, 11, pp. 1145-1150. https://doi.org/10.1134/ S1061934816110034. 
5. Deineka V.I., Kulchenko Y.Y., Deineka L.A. et al., Sorbtsionnye i khromatograficheskie protsessy, 2016, Vol. 16, No 4, pp. 464-471.

Кульченко Ярослава Юрьевна - аспирант кафедры общей химии, Белгородский государственный национальный исследовательский университет, Белгород,

Дейнека Виктор Иванович - профессор кафедры общей химии, д.Х.н., Белгородский государственный национальный исследовательский университет, Белгород

Чулков Андрей Николаевич - старший научный сотрудник, к.т.н., ФГБОУ Белгородский филиал «Центр оценки качества зерна и продуктов его переработки», Белгород

Сидоров Артем Николаевич - аспирант кафедры общей химии, Белгородский государственный национальный исследовательский университет, Белгород

Дейнека Людмила Александровна - доцент кафедры общей химии, к.х.н., Белгородский государственный национальный исследовательский университет, Белгород

Селеменев Владимир Федорович - зав. кафедрой аналитической химии, д.х.н., Воронежский государственный университет, Воронеж
6. Deineka V.I., Deineka L.A., Saenko I.I. et al., Russian Journal of Physical Chemistry A, 2015, Vol. 89, No 7, pp. 1300-1304. https://doi.org/10.1134/S0036024415070079.

Kulchenko Yaroslava Yu. - Postgraduate of General Chemistry Chair, Belgorod National Research University, Belgorod, kulchenko.1992@mail.ru

Deineka Victor I. - Dr.Sc. (Chemistry), Professor of General Chemistry Chair, Belgorod National Research University, Belgorod, deineka@bsu.edu.ru

Chulkov Andrey N. - Senior Researcher, Ph.D., FGBUU Belgorod Branch "Center for Evaluation of the Quality of Grain and Products of Its Processing", Belgorod, Ach87@mail.ru

Sidorov Artem N. - Postgraduate of General Chemistry Chair, Belgorod National Research University, Belgorod, 428026@bsu.edu.ru

Deineka Ludmila A. - Ph.D. (Chemistry), Assistant Professor of General Chemistry Chair, Belgorod National Research University, Belgorod, deyneka@bsu.edu.ru

Selemenev Vladimir F. - Head. Department of Analytical Chemistry, Doctor of Chemical Sciences, Voronezh State University, Voronezh 